УДК 392 (477.85) «17/19»

DOI: $10.15587 / 2313-8416.2015 .37629$

\title{
ІСТОРІЯ ПРОФЕСІЙНОЇ АКУШЕРСЬКОЇ ДОПОМОГИ НА ТЕРИТОРІЇ БУКОВИНИ (ІІ пол. XVIII - 70-ті рр. ХX ст.)
}

\section{(C) К. В. Парайко}

У статті простежуються особливості функціонування акушерської допомоги в нових умовах; розглядається діяльність акушерської школи та відкриття пологових будинків, перехід від допомоги породіллі сільських повитух до кваліфікованої медичної допомоги. Описується зміна структури, кількості та кваліфікації медичного персоналу відповідно до вимог часу. На основі архівних даних описуються три періоди акушерської служби Буковини

Ключові слова: акушерство, пологовий будинок, акушерська школа, Північна Буковина

The peculiarities of obstetrical care in the new conditions are traced in the article; obstetrical school activities and opening of maternities, transition from help of rural midwives for mothers to qualified healthcare are considered. The change in the structure, number and qualification of medical personnel in accordance with the requirements of the time are described. Based on of archival data it is described three periods obstetrical service of Northern Bukovina

Keywords: obstetrics, maternity, obstetrical school, Northern Bukovina

\section{1. Вступ}

«Повивальна справа» - одна 3 найдавніших жіночих професій, а тому окремої уваги заслуговує вивчення умов, за яких відбувалося становлення організації допомоги жінці-породіллі на Буковині. Але народний інститут родопомочі в особі повитухи продовжував існувати тривалий час. Деякою мірою цьому сприяли й історичні обставини - війни, голодомор, колективізація тяжкі умови примусової праці в колгоспі. Як наслідок, увесь цей час звичайна повитуха уособлювала собою “альтернативну” сільську медицину, стрижнем якої були “натуральні”, природні пологи. Допомога «ненавчених» повитух починає відходити в минуле, а на зміну їм приходить кваліфікована медична допомога.

\section{2. Постановка проблеми}

Мета даного дослідження полягає у вивченні становлення професійної акушерської допомоги на Буковині, а також переході від допомоги породіллі сільських повитух до кваліфікованої медичної допомоги. Хронологічні рамки охоплюють період II пол. XVIII - 70-ті pp. XX ст. Верхня хронологічна межа зумовлена пошуком перших відповідних медичних кадрів для створення професійної акушерської допомоги; а нижня хронологічна межа відповідає створенню ФАПів і цілковитому переході до стаціонарного медичного обслуговуванню жінок.

\section{3. Літературний огляд}

Джерельна база представлена матеріалами, які отримані в Державному архіві Чернівецької області (далі ДАЧО), ознайомившись 3 якими ми можемо відтворити картину медичної допомоги на Буковині. Нами опрацьовані статистичні дані народжуваності пологових будинків Чернівецької області (19181970-ті рр.), протоколи вступних і випускних іспитів в учениць акушерської школи, Постанови Міністерства охорони здоров'я про порядок і терміни навчання в акушерській школі, справи про непро- фесійну допомогу з акушерства (за період 1930-х рр.) тощо.

Окремі аспекти створення школи повитух та відкриття пологових будинків розглядали буковинські медики Ніцович І. Р., Юзько О. М., Кобилянський С. Д., Пішак В. П., Дробніс Б. Я. Вони висвітлили деякі питання становлення та розвитку охорони здоров'я та медичної науки Буковини.

Українська дослідниця родильної обрядовості Олена Боряк в статтях «Стан народного акушерства в XIX ст.», «Традиційна культура та новації за радянської доби: особливості співіснування повитухи та акушерки у 20-70-х рр. XX ст.» проаналізувала урядові заходи щодо становлення акушерської допомоги в сільських місцевостях у 20-70-х рр. ХХ ст.

4. Історичний огляд основних періодів становлення професійної акушерської допомоги на Буковині

Історія становлення акушерської служби Північної Буковини охоплює 4 періоди: австрійський (1811-1919 рр.), румунський (1919-1944 рр.), радянський (1944-1991) та український (з 1991 р.). В даній статті ми розглянемо перші три періоди, а саме до 1970-х pp., адже саме в цей час родопомічну допомогу на себе перебрали ФАПи (фельдшерськоакушерські пункти) 3 кваліфікованою допомогою лікарів.

Під час панування Австро-Угорської імперії, Буковина розглядалася лише як сировинний придаток, а тому не докладалося великих зусиль в економічному та соціальному розвитку краю.

За роки панування Австро-Угорської імперії організовано лише 7 лікарень, акушерська допомога в стаціонарах була платною. Кількість пологів коливалася в межах 5-7 \% [2].

Масові заходи щодо поліпшення стану повивальної справи в Україні припали на другу половину XVIII ст. У 1770 р. на західноукраїнських землях, які входили до складу Австро-Угорщини, 
було прийнято «Головний Санітарний Статут», яким передбачалося запровадження у селах так званих «службових» акушерок із розрахунку - одна родопомічниця на два-три населених пункти [3].

Перший медичний персонал у кількості двох фельдшерів з'явився в Чернівцях у військовому шпиталі, заснованому в 1779 р. Процес створення спеціального медичного навчального закладу на Буковині розпочавсяу 1779 році, коли головний хірург Буковини доктор Йосиф Глабах отримав від військового управителя краю барона фон Енценберга завдання - відшукати відповідні медичні кадри для створення професійної системи акушерської допомоги (на той час у Чернівцях пологи приймали дві акушерки) [ДАЧО 1.1]. Перша медична посада в Чернівцях з'явилася 1782 року - запровадженням посади санітарного референта, почали організовувати курси підготовки акушерок [ДАЧО 1.2].

На гостру проблему із забезпеченням медичними кадрами на Буковині, була приділена особлива увага в директиві Галицького губернаторства від 1807 року. Звертаючись до окружного управління Буковини, Львівське губернаторство закликало запобігати вищезгаданим явищам та встановити жорсткий контроль за діяльністю «напівакушерок» (бабок-повитух),перевіряючи їх на професійну придатність [4].

У 1808 році для приведення системи акушерської допомоги на Буковині до певних загальнодержавних стандартів була розроблена інструкція для акушерок (очевидно, за зразком львівських інструкцій, які на той час вже існували). Інструкція опублікована двома мовами (німецькою та польською) i містила 12 параграфів,які містили повноваження акушерок. Зокрема, займатися практикою дозволялося лише дипломованим акушеркам, діяльність яких контролювалася владою. А в параграфах 10-11 Інструкції акушеркам заборонялося виконувати або сприяти проведенню незаконних абортів. У 1809 році при лікарні почало функціонувати пологове відділення, у якому прохо-дили практичну підготовку акушерки, розпочала діяльність школа практичного акушерства, а першою окружною акушеркою була Марія Теодорин [5].

Таким чином, формалізація акушерської справи на Буковині створила необхідність для професіоналізації акушерських кадрів,центром якої стала Чернівецька акушерська школа, яку відкрито у жовтні 1811 року у приміщенні колишніх військових казарм (Чернівецький медичний коледж Букови-нського мед університету - на сьогодні найстаріший в Україні після мед коледжу м. Львова). Структура, форма та зміст навчального процесу були типовими, як i в інших школах Австро-Угорщини, які діяли у Відні, Празі, Кракові, Трієсті, Львові. В акушерські школи приймали осіб обох статей від 20 до 35 років. Обов'язкові умови для вступу - вміння вільно читати, писати i виконувати арифметичні дії (оскільки на Буковині було багато неписьменної молоді,особливо сільської, тому цей пункт умови пізніше було скасовано). Навчальний курс,який тривав один семестр (жовтень-травень),передбачав вивчення теоретичних дисциплін (терапія,хірургія, акушерство,догляд за матір'ю i дитиною) i практичне навчання [6].

У 80-х роках професором школи Й. Волчинським підготовлено «Проект реформування акушерської справи на Буковині», в якому наголошувалося на необхідності удосконалення професійного і духовного рівня майбутніх акушерок, ï важливості в розвитку системи родопомочі. Наприкінці XIX ст. на базі акушерської школи організовуються курси підвищення акушерської кваліфікації [5].

Незважаючи на те,що ситуація із забезпеченням Буковини акушерськими кадрами покращилася (кількість акушерок зросла зі 150 у 1870 р. до 300 у 1900 р.), смертність новонароджених залишалася високою - 33 \%. Особливо високою була дитяча смертність. Власне, це підтверджує офіційна статистика. У 1857 p. на Буковині народилося 28,9 тисяч дітей, а померло понад 14 тисяч, в 1865 році - 21,5 тисяч та 15,5 тисяч відповідно, або більше половини. Наприкінці XIX ст. смертність на Буковині дорівнювала 40 \% від народжуваності, тоді як у Швейцарії - 7,6 \%; в Англії - 14,5\%.

Важливість акушерської допомоги на селі підкреслювалася і тим, що лікарів там не було, тому ті акушерки, які все ж таки залишалися працювати у сільській місцевості,користувалися серед селян особливою повагою.

В 1866 році почав діяти Буковинський публікний лікувальний заклад та при ньому - крайовий пологовий будинок на 15 ліжок (у 1911 р. - 25 ліжок) по вул. св. Ніколауса №6 (нині вул. М. Садовського) [ДАЧО 1.3]. Його об'єднали зі школою акушерок i назвали крайовим інститутом,де навчання акушерок проводилося німецькою, польською, українською мовами.

На початку 70-х pp. XIX ст. Чернівецька акушерська школа, внаслідок загальноімперської реорганізації системи освіти,отримала новий статус державного навчального закладу 3 відповідним фінансуванням. Відтепер дипломовані випускниці школи мали право на працевлаштування по усій території Австро-Угорщини. Покращилося становище викладацько-лікарського складу, підвищено заробітну плату,збільшено кількість професорських вакансій, а після остаточного відокремлення школи від пологового будинку (в 90-ті роки XIX ст.) доповнено новими штатними одиницями: ординаріус та асистент, які виконували функції фінансовогосподарського управління. Асистент також виконував роль перекладача лекцій тим студентам, які не володіли німецькою мовою. За складом студенти були різних національностей - німці, румуни, поляки,євреї, українці [7].

Поступово на початку XX ст. адміністрація школи запроваджує двомовне навчання. У зв'язку 3 необхідністю впорядкування мовних розбіжностей та збільшенням набору студентів крайова адміністрація підвищила фінансування школи на оновлення матеріально-навчальної бази. Змінилися умови 
вступу - збільшувався до 40 років віковий ценз, селяни від іспитів звільнялися.

На поч. XX ст. пологовий будинок було переведено до колишнього приміщення крайової агрономічної школи по вул. Семигородській (сучасна вул. Головна, 129). В міжвоєнний період цей заклад носив назву Інституту гінекології та акушерства доктора О. Георгіана. Він мав 3 відділення та був розрахований на 80 лікувальних місць. В закладі щорічно проходили навчання 20 учениць аку-шерської школи. В ній за період з 1812 по 1926 р. було підготовлено понад 2,5 тис. акушерок [ДАЧО 1.4].

18 лютого 1912 року на основі декрету Галицького губернського управління відкритий пологовий будинок (нині клінічний пологовий будинок №1 м.Чернівці) [ДАЧО 1.5].

Серед усього кола пологових справ чільне місце займало завдання створення дійової системи родопомочі всім жінкам, незалежно від місця їхнього проживання та статків. Слід звернути увагу на той аспект, що на відміну від сільської місцевості приймання пологів в умовах міста було контрольованим, адже завжди була можливість скаржитися у випадку надання некваліфікованої та несумлінної допомоги. Про масштаби цього явища судити важко, адже в судовому порядку розглядалися найбільш складні випадки, та й ті представлені в архівних матеріалах епізодично [ДАЧО 1.6].

Високий рівень підготовки акушерок, який відповідав європейським стандартам дозволяв випускницям Чернівецької школи працювати в різних містах і селах Австрії [8].

За часів австрійського та румунського панування на Буковині акушерська школа у Чернівцях залишалася єдиним медичним закладом, що діяв на той час на теренах нашого краю. До І світової війни тут було підготовлено 500 спеціалістів акушерської справи. Проте більша частина міщанок і всі сільські жінки народжували вдома та обслуговувалися мошами (бабками - повитухами) [9].

Перед Першою світовою війною пологи почали приймати також у повітових лікарнях. Більш частина міщанок і всі сільські жінки народжували вдома та обслуговувалися бабками-повитухами, які не мали медичної освіти. Лише деякі 3 них мали можливість користуватися послугами приватних лікарів та акушерок. На початку XX ст. із 336 сільських общин Північної Буковини не мали жодної акушерки, у 145 - акушерсько-гінекологічна допомога не надавалася зовсім [ДАЧО 1.7]. Ряд акушерок, переважно в сільській місцевості, займалися приватною практикою (не завжди маючи відповідну освіту). Проте для цього необхідний був спеціальний дозвіл [ДАЧО 1.8].

Будівництво корпусу пологового будинку по вул. Трансильванії (потім Семигородська, Зибенбюргерштрассе, а нині - вул. Головна, 129) велося за проектом німецького архітектора Еріха Кобенгайера [ДАЧО 1.9]. У 1896 році зведений перший поверх, а наприкінці 1897 р. будівля була завершена. До 1912 р. тут містилася Крайова сільськогосподарська школа. В результаті переобладнання місто отримало сучасно оснащений пологовий будинок з ванними кімнатами, кухнею, операційним залом, лікувальними палатами [ДАЧО 1.10].

18 лютого 1912 р. на основі декрету Галицького губернського управління відкритий пологовий будинок (при ньому акушерська школа). Директором акушерської школи був головний лікар пологового будинку, політичний діяч краю Октавіан Георгіан [ДАЧО 1.11]. У 1912-14 рр. було підготовлено близько 200 акушерок [10].

Відкрившись після реконструкції у 1913 р. пологовий будинок містив одну пологову залу, одну палату септичну та одну - асептичну для операцій, 14 палат для хворих. Обслуговували пацієнтів двоє лікарів та дві санітарки. Головний лікар пологового будинку доктор Октавіан Георгіан збільшив кількість ліжок, довівши їх до 40 (у 1915 році - до 75 ліжок), лікарів - до 6, санітарок - до 8. Доктор Модест Попеску створив у пологовому будинку гінекологічне відділення на 20 ліжок . Кількість хворих постійно зростала: 1897 р. - 187 хворих; у 1914 р. 1186, а у 1916 р. лише 184, у зв'язку з тим, що у 1916 р. в пологовому будинку розташовувався військовий лазарет [11]. Головною перепоною на шляху до лікування була висока плата за перебування у лікарні.

Із звершенням у 1918 р. Першої світової війни i включенням Буковини до складу Королівської Румунії в 1919 р., звершився «австрійський» період історії акушерської школи. Чернівецька акушерська школа, яка підготувала за роки свого існування понад тисячу освічених акушерок,започаткувала собою розвиток середньої медичної освіти на Буковині [ДАЧО 1.12].

Із захопленням в січні 1918 р. Бессарабії (нині Хотинський і частково Кельменецький райони), а в листопаді того ж року й північної Буковини, на цих землях соціально-економічна і політична ситуація погіршилась. Це стосувалось і матеріального добробуту i, зокрема, охорони здоров'я населення [12].

У 1919 р. відбувся перший «румунський» набір студентів і відкриття акушерської школи. Внаслідок жорстких умов вступу обов'язкова початкова освіта, селянське походження і володіння румунською мовою, навчання в першому семестрі було фактично зірване, оскільки переважна більшість сільської молоді була україномовною. Заняття тривали спочатку 6 місяців, потім один рік, а з 1922 р. термін навчання подовжено до 2-х років. Але разом 3 тим, діяла заборона викладання українською мовою, що обмежувало можливість підготовки акушерок з числа корінного населення краю - українських жінок. У цій школі працювали 3 викладачки, 2 наглядачки та 2 акушерки. Румунізація навчального процесу в акушерській школі негативно позначилася на кількості підготовлених акушерок. Якщо до Першої світової війни на Буковині нараховувалося майже 500 акушерок, то в 1922 р. їх було не більше 150, а наприкінці 30-х рр. ця кількість зменшилася до 100 чоловік [13].

Внаслідок зменшення кількості акушерських кадрів зросла дитяча смертність. 3 метою виправ- 
лення такої негативної ситуації румунська адміністрація зобов'язувала випускниць акушерської школи відпрацювати 5 років після завершення нав-чання на селі. Дипломи видавалися лише після проходження студентами двомісячної практики на селі. Гарантами таких зобов'язань виступали чоловіки акушерок.

У 1932-1933 роках було споруджено перше приміщення для громадської міської лікарні. У 1940 році налагоджується стабільна мережа державних медичних та полого допоміжних закладів. Значно збільшується кількість лікарняних ліжок в обласному пологовому будинку та відкрито кілька відділень і палат в районних та дільничних лікарнях, сформовано пологові ліжка у 23 фельдшерськоакушерських пунктах області. Тоді на Буковині вже працювало 14 акушерів-гінекологів [ДАЧО1.13].

3 27-28 червня 1940 року, після воз'єднання Північної Буковини та Хотинщини з Україною, розпочались соціально-економічні перетворення, у тому числі, і в сфері охорони здоров'я. 1940 р. було розгорнуто лікарняну мережу: 18 пологових будинків та акушерських пунктів на 105 пологових ліжок. Лікарняна мережа мала 1100 ліжок, 3 них: гінекологічних в пологових будинках - 55. У пологових будинках та лікарнях прийнято 475 пологів, у тому числі, у 127 породіль 3 сіл [ДАЧО 1.14].

3 початком встановлення радянської влади на Буковині проведена чергова реорганізація місцевої системи медичної освіти. У звичайно важких умовах завершального року війни та повоєнної розрухи поновлював свою діяльність 2-й Київський державний медичний університет (КДМІ), а 320 жовтня 1944 р. - Чернівецький державний медичний інститут (ЧДМІ), у формуванні науково-кадрового потенціалу якого взяли участь провідні вищі навчальні заклади Радянського Союзу [3].

У 1945 році при обласних та міських лікарнях відновили свою діяльність курси медичних сестер 3 піврічним терміном навчання. Вже за перший рік було підготовлено 60 медсестер. Система середньої медичної освіти в перші повоєнні роки складалася 3 профілюючих шкіл: фельдшерська, акушерська, акушерськофельдшерська,фармацевтична, зуботехнічна, школа лаборантів та школа медсестер, до яких приймалися особи віком від 15 до 35 років із неповною та повною середньою освітою. Число померлих дітей у післявоєнні роки скоротилося в порівнянні з 1940 роком більше ніж удвічі. 3 цього ж року почалась інтенсивна відбудова та організація нових лікувальних закладів, у тому числі, і родопомічних. Було відкрито 5 пологових будинків, нараховувалось 310 акушерських ліжок, 292 фельдшерсько-акушерських пункти. У 1946 році на 135 ліжок працювало 10 лікарів, зареєстровано 2578 пологів, 10 кесарських розтинів, 10 плодоруйнівних операцій, 29 випадків накладання акушерських щипців [ДАЧО 1.15].
Як бачимо на території Буковини існувало два види акушерської допомоги. Тривале співіснування на теренах України «альтернат-тивного» акушерства 3 одного боку - в особі повитухи, 3 другого - дипломованих «акушерок», що подекуди мало характер відкритого або прихованого протистояння, дало можливість проаналізувати наслідки зіткнення традиційних та інноваційних підходів у галузі родопомочі.

Варто зауважити, що негативне ставлення до повитух з боку професійний медиків було загалом традиційним.

В Державному архіві Чернівецької області містяться звіти пологових будинків, згідно яких простежується прагнення держави контролювати процес народжуваності на Буковині. Як приклад можемо розглянути один із таких Статистичних звітів на прикладі Сторожинецького Райздраввідділку (табл. 1, 2)

Таблиця 1

Статистичні звіти Сторожинецького Райздраввідділу з 1931 по 1940 рр. включно про народжуваність, смертність дітей до 4-ох років

\begin{tabular}{|c|c|c|c|c|}
\hline Рік & $\begin{array}{c}\text { Кіль- } \\
\text { кість } \\
\text { народ- } \\
\text { жених }\end{array}$ & $\begin{array}{c}\text { Кіль- } \\
\text { кість } \\
\text { мертво- } \\
\text { народ- } \\
\text { жених }\end{array}$ & $\begin{array}{c}\text { Кіль- } \\
\text { кість } \\
\text { мертвих } \\
\text { дітей від } \\
0-1 \text { p. }\end{array}$ & $\begin{array}{c}\text { Кіль- } \\
\text { кість } \\
\text { мертвих } \\
\text { дітей від } \\
1-4 \text { p. }\end{array}$ \\
\hline 1931 & 1685 & 18 & 300 & 83 \\
\hline 1932 & 1813 & 21 & 335 & 132 \\
\hline 1933 & 1713 & 25 & 280 & 96 \\
\hline 1934 & 1705 & 25 & 385 & 125 \\
\hline 1935 & 1700 & 24 & 346 & 124 \\
\hline 1936 & 1878 & 19 & 281 & 81 \\
\hline 1937 & 1890 & 24 & 318 & 90 \\
\hline 1938 & 1766 & 19 & 290 & 97 \\
\hline 1939 & 1677 & 17 & 234 & 85 \\
\hline 1940 & 923 & 12 & 199 & 36 \\
\hline Загальна кількість дітей до 4 років - 3836 \\
Загальна кількість дітей від 4 до 18 років - 13051 \\
\hline \multicolumn{5}{|l|}{} \\
\hline
\end{tabular}

Таблиця 2

Статистичні звіти Сторожинецького Райздраввідділу з 1931 по 1940 рр. включно про смертність жінок під час абортів і пологів

\begin{tabular}{|c|c|c|}
\hline Рік & $\begin{array}{c}\text { Кількість жінок, що } \\
\text { померли під час } \\
\text { пологів }\end{array}$ & $\begin{array}{c}\text { Кількість жінок, } \\
\text { що померли від } \\
\text { аборту }\end{array}$ \\
\hline 1931 & 8 & 3 \\
\hline 1932 & 8 & 4 \\
\hline 1933 & 6 & 5 \\
\hline 1934 & 10 & 6 \\
\hline 1935 & 4 & 3 \\
\hline 1936 & 6 & 3 \\
\hline 1937 & 9 & 6 \\
\hline 1938 & 3 & 2 \\
\hline 1939 & 6 & 4 \\
\hline 1940 & 1 & - \\
\hline
\end{tabular}


Післявоєнна відбудова сільського господарства, соціально-економічні зрушення позначилися на поступовому поверненні до нормального життя. Медики повернулися до ідеї надання допомоги породіллі через відновлення діяльності насамперед ФАПів. На це, зокрема, націлювала Постанова Президії Верховної Ради СРСР, ухвалена ще 8 червня 1944 р. Як свідчить аналіз наявного матеріалу, у післявоєнні роки більшого пріоритету надавалося розвиткові ФАПів, відкриттю сільських дільничних лікарень із виділенням акушерських ліжок, районних пологових будинків або акушерських відділень.

Процес витіснення повитух акушерками у кожному регіоні мав свою специфіку. На території Західної України організація родопомочі відбувалася досить повільно. Проте, у міру того, як мережа ФАПів та амбулаторних дільниць розгорталася, а допомога медичних кадрів ставала доступнішою.

Кульмінацією цього протистояння між непрофесійними мошами та навченими акушерками, очевидно, став 1960 р., коли офіційна медицина звітувала, що материнську смертність на селі повністю викорінено. Родопомічну та профілактичну допомогу поступово перебирали на себе ФАПи, а стаціонарне обслуговування породіль відбувалося вже у центральних районних та дільничних лікарнях за участю кваліфікованих лікарів [13].

У Чернівецькій області до 1954 р. існувало три таких школи: у Чернівцях - фельдшерсько-акушерська школа і школа медсестер; у Сторожинці школа медсестер. У $1945-47$ pp. Чернівецькою фельдшерсько-акушерською школою підготовлено 184 акушери-фельдшери (за 200 років свого існування коледж підготував 17 тисяч медичних працівників) [ДАЧО 1.16].

У 1979 році відкрито новий акушерський корпус пологового будинку №1 по вул. Буковинська, 1А. У 1988 році збудовано пологовий будинок № 2 по вул. Рівненська, 8 [13]. В області працює 175 лікарів-акушерів [ДАЧО 1.17].

\section{4. Висновки}

Процес становлення професійної системи акушерської допомоги на Буковині затягнувся на декілька десятиліть. I, мабуть, справа не в нестачі матеріальної кадрової бази,а скоріше в довірі повитухам. «Бабка» уміло застосовувала мануальну терапію, дію вогню, а також різні фізіологічні прийоми (могли виправляти під час пологів ручними засобами неправильні положення плода). Повитуха добре володіла ситуацією, зважала на умови життя i побуту породіллі, іiі дії часто сприяли зняттю емоційного напруження і мали психотерапевтичний характер. Факти свідчать, що на початковому етапі запровадження професійної медичної допомоги у породіллі зберігалася можливість вибору між повитухою і акушеркою. Проте, вже в 60-70-х pp. XX ст. медична допомога витісняє сільських бабокповитух.

\section{Література}

1. Державний архів Чернівецької області: 1.1 Ф.13. Оп.2. - Спр.228. - 4арк.; 1.2 Ф.14. - Оп. 2. - Спр. 253. - 204 арк.; 1.3 Ф.19. - Оп.1.- Спр.48. - 61 арк.; 1.4 Ф.286. - Оп. 1. - Спр. 532. - 9 арк.; 1.5 Ф. 286. - Оп. 1. - Спр.681. - 3 арк.;1.6 Ф.286. - Оп.1. - Спр.299. 1.7 Ф. 286 - Оп. 1. Спр.803. - 23 арк.; 1.8 Ф.286. - Оп.1. - Спр.487. - 18 арк.; 1.9 Ф.286. - Оп.1. - Спр. 18. - 9 арк.; 1.20 Ф.286. - Оп.1. Спр.709. - 17арк. 1.21 Ф.286. - Оп.1. - Спр. 33. - 7 арк.;1.22 Ф.286. - Оп.1. - Спр.536. - 45 арк.; 1.23 Ф.286. - Оп.1. Спр.396.- 21 арк.; 1.24 Ф.286. - Оп.1. - Спр.824. Зарк.;1.25 Ф.286. - Оп.1. - Спр.813. - 5 арк.; 1.26 Ф.286. Оп.1. - Спр. 862. - 13 арк.; 1.27 Ф.Р-6. - Оп.1. - Спр.12.

2. Бойчук, Т. М. Історія розвитку акушерства та гінекології на Північній Буковині [Текст] / Т. М. Бойчук, I. Д. Шкробанець, О. М. Юзько, О. А. Андрієць, I. Р.Ніцович // Неонатологія, хірургія та перинатальна медицина. - 2013. - № 4 (10). - С. 153-159.

3. Боряк, О. О. Традиційна культура та новації за радянської доби: особливості співіснування повитухи та акушерки у 20-70-х pp. XX ст. [Текст] / О. О. Боряк // Етнічна історія народів Європи. - 2009. - Вип. 29. C. 11-21.

4. Боряк, О. О. Стан народного акушерства в ХІХ ст. [Текст] / О. О. Боряк // Український історичний журнал. 2001. - № 2. - C. 49-61.

5. Білоус, В. І. Нариси 3 історії медицини та фармації в питаннях і відповідях від первісних до нових часів (з елементами медичної етики і деонтології) [Текст] / В. І. Білоус, В. В. Білоус, М. І. Грицюк, Т. М. Воротняк; за ред. В. Е. Кардаша. - Чернівці, 2010. - 132 с.

6. Кобилянський, С. Д. Історія медицини Буковини. Цифри й факти / С. Д. Кобилянський, В. П. Пішак, Б. Я. Дробніс. - Чернівці: Видавництво БДМА, 1999. - 249 с.

7. Ганіткевич, Я. Історія української медицини в датах та іменах [Текст] / Я. Ганіткевич. - Львів, 2004. - 368 с.

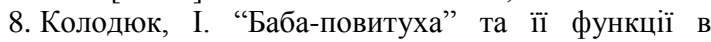
народній медицині жителів Полісся наприкінці XIX - на початку XX століття (за експедиційними матеріалами) [Текст] / I. Колодюк // Етнічна історія народів Європи: зб. наук. пр. - 2004. - Вип. 17. - С. 77-82.

9. Ніцович, І. Р. Нарис з історії пологового будинку № 1 м. Чернівці [Текст] / I. Р. Ніцович // «Хист» Всеукраїнський медичний журнал молодих вчених. - 2006. № 8 . - С. $78-86$.

10. Польова, С. П. Розвиток акушерської служби Північної Буковини [Текст] / С. П. Польова, І. Р. Ніцович // Клінічна анатомія та оперативна хірургія. - 2009. - Т. 8, № 4. - C. 91-96.

11. Руснак, О. Лікарняна служба Північної Буковини і Хотинщини у міжвоєнний період [Текст] / О. Руснак // Наука i освіта: крок у майбутнє. Матеріали VI Міжнародної наукової конференції «Кайндлівські читання», присвячен 145-річчю від дня народження Р. Ф. Кайнд-ля. - Чернівці-Вижниця: Черемош, 2011. C. 461-464.

12. Юзько, О. М. Історія кафедри акушерства i гінекології з куррсом дитячої та підліткової гінекології Буковинської державної медичної академії. [Текст] / О. М. Юзько // Клінічна анатомія та оперативна хірургія. 2003. - T. 2, № 4. - С. 76-82.

13. Грищенко, В. И. Научные основы регулирования рождамости [Текст] / В. И. Грищенко. - К.:Здоров'я, 1983. $-208 \mathrm{c}$.

\section{References}

1. Derzavnyj arhiv Chernivec'koi oblasti: 1.1 F.13. Op. 2. - Spr. 228. -4 ark.; 1.2 F.14. - Op. 2. - Spr. 253. 204 ark.; 1.3 F.19. - Op. 1. - Spr. 48. - 61 ark.; 1.4 F.286. Op. 1. - Spr. 532. -9 ark.; 1.5 F.286. - Op. 1. - Spr. 681. -3 ark.; 1.6 F.286. - Op. 1. - Spr. 299. - 18 ark.; 1.7 F.286. - Op. 1. - Spr. 803. -23 ark.; 1.8 F.286. - Op. 1. - Spr. 487. -18 
ark.; 1.9 F.286. - Op. 1. - Spr. 18. - 9 ark.; 1.20 F.286. - Op. 1. - Spr. 709. -17 ark.; 1.21 F.286. - Op. 1. - Spr. 536. - 7 ark.; 1.22 F.286. - Op. 1. - Spr. 536. - 45 ark.; 1.23 F.286. - Op. 1. - Spr. 396. - 21 ark.; 1.24 F.286. - Op. 1. - Spr. 824. - 3ark.; 1.25 F.286. - Op. 1. - Spr. 813. - 5 ark.; 1.26 F.286. - Op. 1. Spr. 862. -13 ark.; 1.27 F.P-6. - Op. 1. - Spr. 12. -22 ark.

2. Boychiyk, T. M., Shkrobanets', I. D., Yuz'ko, O. M., Andriets, O. A., Nicovych, I. R. (2013). Istoria rozvytku akusherstva I ginekologii na Pivnichniij Bukovyni [The history of obstetrics and gynecology at the North Bukovina]. Neonatology, surgery and perinatal medicine, 4, 153-159.

3. Boriak, O. O. (2009). Tradycijna kul'tura ta novacii za radians'koi doby: osoblyvosti spivisnuvannia povytuhy ta akusherky u 20-70-h rr. XX st. [Traditional culture and innovations in the Soviet era, coexistence features midwives and midwives in the 20-70's. XX century]. Ethnic history of the peoples of Europe, 29, 11-21.

4. Boriak, O. O. (2001). Stan narodnogo akysherstva v XIX st. [State of national midwifery in XIX century]. Ukrainian Historical Journal, 2, 49-61.

5. Biloys, V. I., Biloys, V. V., Gryciyk, M. I., Vorotniak, T. M. (2010). Narysy $\mathrm{z}$ istorii medyzyny ta farmacii $\mathrm{v}$ pytanniah I vidpovidiah vid pervisnyh do novyh chasiv ( $\mathrm{z}$ elementamy medychnoi etyky i deontologii) [Essays on the History of Medicine and Pharmacy in questions and answers from primitive to modern times (with elements of medical ethics and deontology)]. Chernivtsi, Ukraine, 132.

6. Kobylyansky, S. D., Pishak, V. P., Drobnis, B. Ia. (1999). Istoria medycyny Bukovyny. Cyfry I fakty. [ History of
Medicine Bukovina. The numbers and facts]. Chernivtsi, Ukraine, 249.

7. Ganitkevyc, Ia. (2004). Istoria ukrains'koi medycyny $\mathrm{v}$ datah I imenah [The history of Ukrainian medicine in dates and names]. Lviv, Ukraine, 368.

8. Kolodyuk, I. (2004). "Baba-povytuha" I ii funcii v narodnii medycyni zhyteliv Polissia naprykinci XIX- pochatku $\mathrm{XX}$ st. ["Midwife" and her functions in traditional medicine residents Polesie late XIX - early XX century (by forwarding materials)]. Ethnic history of the peoples of Europe, 17, 77-82.

9. Nicovyc, I. R. (2006). Narys $\mathrm{z}$ istorii pologovogo budynky № $1 \mathrm{~m}$. Chernivchi [Essay on the history of Chernivtsi maternity hospital № 1]. Hyst, 78-86.

10. Poliova, S. P., Nitsovych, I. R. (2009). Rozvytok akushers'koi sluzhby Pivnichnoi Bucovyny [The development of obstetric services Northern Bukovina ]. Clinical Anatomy and Operative Surgery, 4, 78-86.

11. Rusnak, O. (2011). Likarniana sluzhba Pivnichnoi Bukovyny i Hotynzhyny u mizhvoennyi period [Hospital Service of Northern Bukovina and Khotyn district between the wars]. Science and education: a step into the future, 461-464.

12. Iuz'ko, O. M. Istoria kafedry akusherstva I ginekologii $\mathrm{z}$ kursom dytiacoi ta pidlitkovoi ginekologii Bukovyns'koi derzhavnoi medycnoi akademii [History of obstetrics and gynecolgy with a course of child and adolescent gynecology Bukovinian State Medical Academy]. Clinical Anatomy and Operative Surgery, 4, 76-82.

13. Grychenko, V. I. (1983). Naucnye osnovy regulirovania rozhdaemosti [Scientific basis of birth control]. Kyiv, Ukraine, 208.

Рекомендовано до публікаџіï д-р істор. наук, професор Кожолянко Г. К. Дата надходження рукопису 27.01.2015

Парайко Крістіна Василівна, аспірант, кафедра етнології, античної та середньовічної історії, Чернівецький національний університет імені Юрія Федьковича, вул. Кафедральна, 2, м. Чернівці, Україна, 58000

E-mail: parajko1989@gmail.com 